\title{
EFEKTIVITAS PENDEKATAN SCIENTIFIC DALAM MATA KULIAH TRIGONOMETRI PADA MAHASISWA PENDIDIKAN MATEMATIKA IKIP PGRI PONTIANAK
}

\author{
Yadi Ardiawan \\ Pendidikan Matematika, IKIP PGRI Pontianak \\ Email: yadi.stkip@gmail.com
}

\begin{abstract}
This study aimed to compare the results between student given learning mathematics instruction in the subject of trigonometry using a scientific approach and which does not use a scientific approach in the Program Studi Pendidikan Matematika PGRI Pontianak. The method used is the method of experimental research, the research form quasi-experimental design. This is because the educational research often are difficult to control manipulate all relevant variables. Results of this study are average student results provided scientific approach that is equal to 24.06 of a maximum score of 40 . That is the percentage of scientific learning outcomes of $60.15 \%$ (quite enough). While the average student results are given learning without a scientific approach that is equal to 20.72 of a maximum score of 40 . That is the percentage of learning outcomes without scientific amounted to 51.8\% (relatively low). It can be concluded that the learning outcomes of students who are taught using a scientific approach is better than the learning outcomes of students who are taught not to use a scientific approach.
\end{abstract}

Keywords: learning outcomes, scientific approach, trigonometry.

\section{PENDAHULUAN}

Tercapai atau tidaknya tujuan pembelajaran matematika salah satunya dapat dinilai dari keberhasilan peserta didik dalam memahami matematika dan memanfaatkan pemahaman ini untuk menyelesaikan persoalanpersoalan matematika maupun ilmu-ilmu yang lain. Lebih khusus lagi dalam pemecahan soal-soal matematika membutuhkan penalaran dan kecermatan peserta didik. Banyak faktor yang mempengaruhi kemampuan peserta didik dalam menyelesaikan masalah yang berhubungan dengan matematika antara lain minat, bakat, fasilitas, pendekatan pembelajaran, kurikulum, dll.

Pemerintah dari tahun ketahun selalu berupaya untuk memperbaharui dan memperbaiki kurikulum supaya hasil yang dicapai peserta didik dapat maksimal. Disadari atau tidak bahwa guru-guru perlu memperkuat kemampuannya dalam memfasilitasi siswa agar terlatih berpikir logis, sistematis, 
ISSN 2442-5419 Vol. 4, No. 2 (2015) 30-41

dan ilmiah. Tantangan ini memerlukan peningkatan

keterampilan guru melaksanakan pembelajaran dengan menggunakan pendekatan ilmiah. Skenario untuk memacu keterampilan guru menerapkan strategi ini di Indonesia telah melalui sejarah yang panjang, namun hingga saat ini harapan baik ini belum terwujudkan juga. Balitbang Depdiknas sejak tahun 1979 telah merintis pengembangan program prestisius ini dalam Proyek Supervisi dan CBSA (Cara Belajar Siswa Aktif) di Cianjur, Jawa Barat. Hasil-hasil proyek ini kemudian direplikasi di sejumlah daerah dan dikembangkan melalui penataran guru keseluruh Indonesia. Upaya yang dimulai pada tingkat sekolah dasar ini kemudian mendorong penerapan pendekatan belajar aktif di tingkat sekolah menengah. Hasil-hasil upaya ini secara bertahap kemudian diintegrasikan ke dalam Kurikulum 1984, Kurikulum 1994, dan Kurikulum Berbasis Kompetensi tahun 2004, yang dilanjutkan dengan Standar Isi yang lebih dikenal dengan istilah Kurikulum Tingkat Satuan Pendidikan (KTSP) tahun 2006 (Fuzinoviyanti, 2013).

Menurut Hanafiah dan Suhana (2009: 6), pandangan tradisional memandang bahwa belajar adalah usaha memperoleh sejumlah ilmu pengetahuan. Pandangan ini menyatakan knowledge is power yaitu barangsiapa yang menguasai pengetahuan maka dia yang akan mendapat kekuasaan. Oleh karena itu, bahan bacaan merupakan sumber atau kunci utama untuk memperoleh ilmu pengetahuan.

Secara filosofis menurut teori konstruktivis dalam Baharudin dan Wahyuni (2010: 116), belajar adalah membangun pengetahuan sedikit demi sedikit yang kemudian hasilnya diperluas melalui konteks yang terbatas. Vygotsky dalam Baharudin dan Wahyuni (2010: 124), belajar adalah sebuah proses yang melibatkan dua elemen penting yaitu belajar merupakan proses biologi sebagai proses dasar dan merupakan proses secara psikososial sebagai proses yang lebih tinggi esensinya berkaitan dengan lingkungan sosial budaya.

Pendekatan adalah konsep dasar yang mewadahi, menginspirasi, menguatkan, dan melatari pemikiran tentang bagaimana metode pembelajaran diterapkan berdasarkan teori tertentu. Oleh karena itu banyak pandangan yang menyatakan bahwa pendekatan sama artinya dengan metode. Pendekatan ilmiah berarti konsep dasar yang menginspirasi atau melatar belakangi perumusan metode mengajar dengan menerapkan karakteristik yang ilmiah. Pendekatan ilmiah (scientific approach) merupakan bagian dari pendekatan pedagogis pada pelaksanaan pembelajaran dalam 
kelas yang melandasi penerapan metode ilmiah. Pengertian penerapan pendekatan ilmiah dalam pembelajaran tidak hanya fokus pada bagaimana mengembangkan kompetensi siswa dalam melakukan observasi atau eksperimen, namun bagaimana mengembangkan pengetahuan dan keterampilan berpikir sehingga dapat mendukung aktivitas kreatif dalam berinovasi atau berkarya. Menurut majalah Forum Kebijakan Ilmiah yang terbit di Amerika pada tahun 2004 sebagaimana dikutip Wikipedia (Fuzinoviyanti, 2013) menyatakan bahwa pembelajaran ilmiah mencakup strategi pembelajaran siswa aktif yang mengintegrasikan siswa dalam proses berpikir dan penggunaan metode yang teruji secara ilmiah sehingga dapat membedakan kemampuan siswa yang bervariasi.

Menurut Atsnan dan Gazali (2013) terdapat tujuh kriteria sebuah pendekatan pembelajaran dapat dikatakan sebagai pembelajaran scientific. 1) Materi pembelajaran berbasis pada fakta atau fenomena yang dapat dijelaskan dengan logika atau penalaran tertentu; bukan sebatas kira-kira, khayalan, legenda, atau dongeng semata. 2) Penjelasan guru, respon siswa, dan interaksi edukatif guru-siswa terbebas dari prasangka yang serta-merta, pemikiran subjektif, atau penalaran yang menyimpang dari alur berpikir logis. 3) Mendorong dan menginspirasi siswa berpikir secara kritis, analistis, dan tepat dalam mengidentifikasi, memahami, memecahkan masalah, dan mengaplikasikan materi pembelajaran. 4) Mendorong dan menginspirasi siswa mampu berpikir hipotetik dalam melihat perbedaan, kesamaan, dan tautan satu sama lain dari materi pembelajaran. 5) Mendorong dan menginspirasi siswa mampu memahami, menerapkan, dan mengembangkan pola berpikir yang rasional dan objektif dalam merespon materi pembelajaran. 6) Berbasis pada konsep, teori, dan fakta empiris yang dapat dipertanggungjawabkan. 7)Tujuan pembelajaran dirumuskan secara sederhana dan jelas, namun menarik sistem penyajiannya.

Dalam Sistem Pendidikan Nasional (Sisdiknas) dijelaskan bahwa Pendidikan Nasional berfungsi untuk mengembangkan kemampuan dan membentuk watak serta peradaban bangsa yang bermartabat dalam rangka mencerdaskan kehidupan bangsa dan bertujuan untuk berkembangnya potensi peserta didik agar menjadi manusia yang beriman dan bertakwa kepada Tuhan Yang Maha Esa, berakhlak mulia, sehat, berilmu, cakap, kreatif, mandiri, dan menjadi warga negara yang demokratis serta bertanggung jawab (UU Sisdiknas, 2003: 4). Sesuai fungsi dan tujuan pendidikan nasional tersebut terletak juga tanggung 
ISSN 2442-5419 Vol. 4, No. 2 (2015) 30-41

jawab guru untuk mampu mewujudkannya melalui pelaksanaan proses pembelajaran yang mampu bermutu dan berkualitas. Sejalan dengan pergantian kurikulum KTSP menjadi kurikulum 2013, istilah pendekatan ilmiah atau scientific approach pada pelaksanaan pembelajaran menjadi bahan pembahasan yang menarik perhatian para pendidik akhirakhir ini. Pada penerapan (implementasi Kurikulum 2013) di sekolah, guru salah satunya harus menggunakan pendekatan ilmiah (scientific), karena pendekatan ini lebih efektif hasilnya dibandingkan pendekatan tradisional. Hal yang menjadi latar belakang pentingnya pelaksanaan ini karena produk pendidikan dasar dan menengah belum menghasilkan lulusan yang mampu berpikirkritis setara dengan kemampuan anak-anak bangsa lain.

Menyikapi

kebijakan

pemerintah yang sedang berupaya mengimplementasikan kurikulum 2013 melalui pendekatan scientific, maka peneliti sebagai seorang dosen juga ingin ikut berpartisipasi dalam kegiatan yang dinilai positif tersebut. Dari pemaparan di atas, peneliti ingin menerapkan pendekatan scientific dalam pembelajaran matematika pada mahasiswa calon guru. Harapannya selain agar mahasiswa mengetahui dan mengalami langsung pembelajaran menggunakan pendekatan scientific, juga peneliti ingin melihat seberapa efektif pendekatan scientific dalam proses kegiatan belajar mengajar.

\section{METODE PENELITIAN}

Menurut Nawawi (2005: 50), "Metode adalah cara yang digunakan untuk mencapai tujuan". Metode yang digunakan dalam penelitian ini adalah metode penelitian eksperimen. Nawawi menyatakan bahwa penelitian eksperimen bertujuan untuk menyelidiki kemungkinan hubungan sebab-akibat dengan cara mengenakan satu atau lebih kondisi perlakuan kepada satu atau lebih kelompok eksperimen". Alasan peneliti untuk menggunakan metode eksperimen karena dalam penelitian ini peneliti ingin mengetahui apakah terdapat perbedaan hasil belajar yang signifikan antara mahasiswa yang diberikan pendekatan scientific dan mahasiswa yang tidak diberikan pendekatan scientific.

Bentuk penelitian yang digunakan dalam penelitian ini adalah Quasy Experimental Design (Eksperimen semu) dengan rancangan penelitiannya adalah Posttest-Only Control Design yaitu rancangan yang menyertakan kelompok kontrol sebagai pembanding (Sugiyono, 2007: 76). Adapun rancangan penelitian ini dapat digambarkan dengan skema sebagai berikut. 
ISSN 2442-5419 Vol. 4, No. 2 (2015) 30-41

Tabel 1. Rancangan Penelitian Posttest-Only Control Design

\begin{tabular}{|c|c|}
\hline $\mathrm{X}$ & $T_{1}$ \\
\hline $\mathrm{Y}$ & $T_{2}$ \\
\hline
\end{tabular}

Keterangan:

$\mathrm{X}=$ Perlakuan menggunakan pendekatan scientific

$\mathrm{Y}=$ Perlakuan tanpa menggunakan pendekatan scientific

$T_{1}=$ Hasil belajar mahasiswa yang diberikan pendekatan scientific

$T_{2}=$ Hasil belajar mahasiswa yang tidak diberikan pendekatan scientific

Variabel bebas adalah variabel yang menjadi sebab berubahnya atau munculnya variabel terikat. Variabel bebas dalam penelitian ini adalah pendekatan pembelajaran (menggunakan scientific dan tanpa menggunakan scientific). Sedangkan Sugiyono (2007: 61) mengemukakan bahwa "Variabel terikat adalah variabel yang dipengaruhi atau yang menjadi akibat, karena adanya variabel bebas". Berdasarkan pendapat tersebut dapat disimpulkan bahwa variabel terikat adalah variabel yang dipengaruhi oleh adanya variabel bebas. Adapun yang menjadi variabel terikat dalam penelitian ini adalah hasil belajar mahasiswa Prodi Pendidikan Matematika IKIP PGRI Pontianak dalammata kuliah trigonometri.

Populasi dalam penelitian ini adalah seluruh mahasiswa Pendidikan Matematika Semester I IKIP PGRI Pontianak (angkatan 2014). Populasi ini terdiri dari 6 rombongan belajar (kelas) yakni 3 kelas pagi (IA, IB \& IC) dan 3 kelas sore (IA, IB\& IC). Pengambilan sampel dalam penelitian ini menggunakan teknik cluster random sampling. Setelah kondisi 6 kelas tersebut dalam keadaan homogen, maka akan dipilih 2 kelas secara acak. Kelas acakan pertama akan diajarkan menggunakan pendekatan scientific dan kelas acakan kedua akan diajarkan tanpa menggunakan pendekatan scientific

Penelitian ini dilakukan pada bulan Oktober 2014 sampai bulan Januari 2015 tahun akademik 2014/2015. Tempat penelitian ini adalah Program Studi Pendidikan Matematika Sekolah Tinggi Keguruan dan Ilmu Pendidikan Persatuan Guru Republik Indonesia (IKIP PGRI) Pontianak yang beralamat di Jl. Ampera, Kecamatan Kota Baru, Kota Pontianak, Kalimantan Barat.

Teknik pengumpulan data dalam penelitian ini menggunakan teknik pengukuran. Pengukuran 
dilakukan dengan pemberian tes hasil belajar yakni Ujian Akhir Semester (UAS) Mata Kuliah Trigonometri. Soal diberikan sesuai dengan jadwal UAS mahasiswa di Program Studi Pendidikan Matematika IKIP PGRI Pontianak. Sedangkan, alat pengumpul data atau instrumen penelitian yang digunakan dalam penelitian ini adalah dengan tes. Jenis tes yang dilakukan dalam penelitian ini adalah tes tertulis dalam bentuk essay. Tes bentuk essay adalah sejenis tes kemajuan belajar yang memerlukan jawaban yang bersifat pembahasan atau uraian kata-kata. Digunakannya tes essay ini sejalan dengan pendapat Arikunto (2010: 163) yang mengatakan; kelebihan tes essay adalah (1) mudah disiapkan dan disusun, (2) tidak memberi banyak kesempatan untuk berspekulasi atau untunguntungan, (3) mendorong mahasiswa untuk berani mengemukakan pendapat serta menyusun dalam bentuk kalimat yang bagus, (4) memberi kesempatan kepada mahasiswa untuk mengutarakan maksudnya dengan gaya bahasa dan caranya sendiri, (5) dapat diketahui sejauh mana mahasiswa mendalami sesuatu masalah yang diujikan.

\section{HASIL PENELITIAN DAN PEMBAHASAN \\ Hasil}

$\begin{array}{lr}\text { Sebelum } & \text { eksperimen } \\ \text { berlangsung, } & \text { kelompok }\end{array}$

eksperimen dan kelompok control diuji keseimbangan rata-ratanya. Untuk melakukan uji keseimbangan digunakan uji $t$ sampel 2 pihak. Data yang digunakan untuk menguji keseimbangan ini adalah nilai pretest mata kuliah Trigonometri. Sebelum uji t 2 sampel digunakan maka terlebih dahulu dilakukan uji persyaratan, yaitu uji normalitas dan uji homogenitas. Pengujian normalitas menggunakan software minitab 16 dengan taraf signifikansi $0,05(5 \%)$. Hasil Uji Nomalitas pre-test kelas yang akan diberikan pembelajaran scientific diperoleh bahwa nilai $\mathrm{p}=0,100$ maka keputusan uji statistiknya adalah menerima $\mathrm{H}_{0}$. Hal ini menunjukkan bahwa sampel berasal dari populasi yang berdistribusi normal. Hasil Uji Nomalitas pre-test kelas yang akan diberikan pembelajaran selain scientific diperoleh bahwa nilai $\mathrm{p}=$ 0,068 . Dengan mengambil taraf signifikansi sebesar 5\% maka keputusan uji statistiknya adalah menerima $\mathrm{H}_{0}$. Hal ini menunjukkan bahwa sampel berasal dari populasi yang berdistribusi normal. Dari uji homogenitas diperoleh $\mathrm{p}=0,140$. Dengan mengambil taraf signifikansi sebesar 5\% maka keputusan uji statistiknya adalah menerima $\mathrm{H}_{0}$. Hal ini menunjukkan bahwa sampel berasal dari populasi yang memiliki variansi yang sama. 
Hasil uji normalitas dan uji homogenitas yang diperoleh menunjukkan bahwa data berdistribusi normal dan homogen. Oleh karena itu, dapat dilakukan uji keseimbangan rata-rata. Untuk pengujian keseimbangan kelas dilakukan ujit 2 sampel 2 pihak. Berikut disajikan data hasil perhitungan menggunakan minitab 16 dengan taraf signifikansi $5 \%$.

Tabel 2. Hasil Uji t 2 sampel 2 pihak data pre-test Trigonometri

\begin{tabular}{|c|c|c|c|}
\hline $\mathrm{p}$-value & $\mathrm{p}-\alpha$ & Kep. Uji & Kesimpulan \\
\hline 0,402 & 0,05 & $\mathrm{H}_{0}$ diterima & Homogen \\
\hline
\end{tabular}

Berdasarkan tabel di atas diperoleh informasi bahwa p-value yang diperoleh sebesar 0,402. Peneliti memilih taraf signifikansi sebesar 5\% atau 0,05. Karena uji 2 pihaksehingga daerah kritis yang digunakan dalam penelitian ini adalah DK = $\{p \mid-0,025<p<0,025\}$. Karena p-value tidak berada di dalam daerah kritis berarti menunjukkan bahwa Ho tidak ditolak dalam artian menerima $\mathrm{H}_{0}$. Sehingga dapat disimpulkan bahwa kemampuan awal Trigonometri kedua kelas adalah sama. Karena kemampuan awal kedua kelas sudah seimbang, maka kedua kelas layak diberikan perlakuan yang berbeda yang selanjutnya akan dikomparasi hasil perlakuan tersebut.

Data dalam penelitian ini adalah data hasil belajar matematika mahasiswa mata kuliah Trigonometri kelas A Sore dan kelas B Sore. Perlu diketahui bahwa kelas A Sore adalah sampel yang diberikan pembelajaran scientific, sedangkan kelas B Sore adalah sampel yang diberikan pembelajaran bukan scientific. Berikut ini dipaparkan deskripsi data hasil belajar mahasiswa matematika pada matakuliah Trigonometri yang diambil berdasarkan skor ujian akhir semester 2014/2015. Adapun skor maksimal yang ditentukan peneliti adalah 40 .

Tabel 3. Hasil Belajar Mahasiswa yang diberikan scientific

\begin{tabular}{|c|c|c|c|c|}
\hline $\mathrm{N}$ & $x_{\min }$ & $x_{\max }$ & $\bar{x}$ & $\mathrm{~s}$ \\
\hline 35 & 10 & 39 & 24,06 & 8,08 \\
\hline
\end{tabular}

Tabel 4. Hasil Belajar Mahasiswa yang tidak diberikan scientific

\begin{tabular}{|c|c|c|c|c|}
\hline $\mathrm{N}$ & $x_{\min }$ & $x_{\max }$ & $\bar{x}$ & $\mathrm{~s}$ \\
\hline 32 & 9 & 40 & 20,72 & 6,92 \\
\hline
\end{tabular}


Untuk menjawab perumusan masalah dalam penelitian ini maka dilakukanlah uji hipotesis. Uji hipotesis dalam penelitian ini menggunakan uji t 2 sampel. Sebelum dilakukan uji t 2 sampel maka dilakukanlah uji prasyarat yang terdiri dari uji normalitas dan uji homogenitas. Perhitungan dalam penelitian ini menggunakan aplikasi minitab 16. Peneliti beralasan menggunakan aplikasi minitab karena dianggap memiliki tingkat keakuratan yang tinggi dibandingkan dengan perhitungan secara manual. Dari perhitungan tersebut diperoleh informasi sebagai berikut.

Tabel 5. Hasil Uji Nomalitas Hasil Belajar Mahasiswa yang diberikan scientific

\begin{tabular}{|c|c|c|c|}
\hline p-value & $\mathrm{p}-\alpha$ & Kep. uji & Kesimpulan \\
\hline 0,071 & 0,05 & $\mathrm{H}_{0}$ diterima & Normal \\
\hline
\end{tabular}

Tabel 6. Hasil Uji Nomalitas Hasil Belajar Mahasiswa yang tidak diberikan scientific

\begin{tabular}{|c|c|c|c|}
\hline p-value & $\mathrm{p}-\alpha$ & Kep. uji & Kesimpulan \\
\hline 0,092 & 0,05 & $\mathrm{H}_{0}$ diterima & Normal \\
\hline
\end{tabular}

Tabel 7. Hasil Uji HomogenitasHasil Belajar

\begin{tabular}{|c|c|c|c|}
\hline $\mathrm{p}$-value & $\mathrm{p}-\alpha$ & Kep. uji & Kesimpulan \\
\hline 0,385 & 0,05 & $\mathrm{H}_{0}$ diterima & Homogen \\
\hline
\end{tabular}

Hasil uji normalitas dan uji homogenitas menunjukkan bahwa data berdistribusi normal dan homogen. Oleh karena itu, dapat dilakukan uji hipotesis. Adapun hasil uji hipotesis menggunakan aplikasi minitab 16 diperoleh hasil sebagai berikut.

Tabel 8. Hasil Uji t 2 sampel pihak kanan Hasil Belajar Trigonometri

\begin{tabular}{|c|c|c|c|}
\hline $\mathrm{p}$-value & $\mathrm{p}-\alpha$ & Kep. uji & Kesimpulan \\
\hline 0,038 & 0,05 & $\mathrm{H}_{0}$ diterima & Homogen \\
\hline
\end{tabular}

Berdasarkan tabel di atas diperoleh informasi bahwa p-value yang diperoleh sebesar 0,038 . Penelitian ini menggunakan taraf signifikansi sebesar 5\% sehingga daerah kritisnya adalah $\mathrm{DK}=$ $\{p \mid p<0,05\}$. Karena p-value berada di dalam daerah kritis berarti menunjukkan bahwa Ho ditolak. Sehingga dapat disimpulkan bahwa hasil belajar mata kuliah Trigonometriyang diajarkan dengan pendekatan scientific lebih baik daripada hasil belajar mahasiswa yang diajarkan 
tanpa menggunakan pendekatan scientific.

\section{Pembahasan}

Berdasarkan hasil penelitian di atas diperoleh informasi bahwa kemampuan awal kedua kelas adalah seimbang. Sehingga kedua kelas layak untuk diberikan perlakuan yang berbeda yang selanjutnya hasil belajarnya akan dikomparasi. Kelas A Sore diberikan perlakuan dengan pendekatan scientific, sedangkan kelas B Sore diberikan pembelajaran tanpa pendekatan scientific (pembelajaran yang biasa digunakan dosen). Pemberian perlakuan kepada kedua kelas adalah sama, artinya tidak ada kelas yang diistimewakan. Bukan karena supaya hasil pembelajaran scientific bagus sehingga kelas yang diajarkan dengan scientific diberikan perhatian penuh, sedangkan kelas lainnya tidak. Melainkan, kedua kelas diberikan perlakuan yang adil. Sehingga di akhir pembelajaran, peneliti dapat melihat efek dari kedua pembelajaran yang diberikan kepada masing-masing kelas.

Berdasarkan deskripsi data hasil penelitian, diperoleh informasi bahwa $\mathrm{H}_{0}$ ditolak. Artinya hasil belajar mahasiswa yang diajarkan dengan pendekatan scientific lebih baik daripada hasil belajar mahasiswa yang diajarkan tanpa pendekatan scientific. Hasil penelitian ini diperoleh setelah dilakukan uji hipotesis menggunakan uji t 2 sampel pihak kanan yang sebelumnya telah dipenuhi uji prasyarat yaitu normalitas dan homogenitas.

Hasil penelitian ini sesuai dengan bunyi hipotesis penelitian yang berbunyi: "hasil belajar mahasiswa yang diajarkan menggunakan pendekatan scientific lebih baik daripada hasil belajar mahasiswa yang diajarkan tidak menggunakan pendekatan scientific". Hal ini dimungkinkan saja, karena pembelajaran dengan pendekatan scientific memang dirasa cocok untuk karakteristik pembelajaran matematika khusunya Trigonometri. Dalam pendekatan scientific terdapat 5 langkah penting yang harus dilakukan yaitu mengamati, bertanya, bernalar/ berpikir, mencoba dan berinteraksi untuk berdiskusi. Sedangkan dalam membelajarkan trigonometri diperlukan pengamatan dalam mengukur sudut, mengamati proses penjabaran turunan rumusrumus trigonometri, bertanya bagi mahasiswa yang merasa bingung dalam penjelasan konsep trigonometri, berpikir cara menemukan sudut-sudut berelasi, berpikir untuk memilih rumus mana yang diperlukan untuk penyelesaian masalah trigonometri dan saling berinteraksi untuk berdiskusi dalam memecahkan masalah dalam kehidupan sehari hari yang berhubungan dengan konsep trigonometri. Sehingga, jika dilaksanakan dengan 
sistematis pendekatan scientific, maka hasil belajar mahasiswa pun akan maksimal.

Hasil pembelajaran mata kuliah Trigonometri pada penelitian ini memang sesuai dengan rumusan hipotesis. Akan tetapi, rata-rata hasil belajar yang diperoleh belum lah maksimal. Hal ini dapat dilihat dari rata-rata hasil belajar mahasiswa yang diberikan pendekatan scientific yaitu sebesar 24,06 dari skor maksimal 40, sedangkan rata-rata hasil belajar mahasiswa yang diberikan pembelajaran tanpa pendekatan scientific yaitu sebesar 20,72. Artinya persentase hasil pembelajaran scientific sebesar $60,15 \%$ (tergolong cukup) dan persentase hasil pembelajaran tanpa scientific sebesar 51,8 \% (tergolong rendah).

Pada pembelajaran scientific, mahasiswa tergolong aktif dalam mengikuti perkuliahan. Selain persentase kehadiran mahasiswa mencapai $100 \%$, dalam perkuliahan mahasiswa sering bertanya dan berdiskusi dengan teman satu kelompok. Setelah mengamati, mahasiswa bertanya apa yang mereka tidak pahami. Kemudian dosen memberikan umpan agar mahasiswa dapat bernalar dan mengkomunikasikan dengan teman satu kelompok apa yang dia pikirkan dan mendiskusikan solusi yang tepat. Artinya dalam pembelajaran scientific tidak ada permasalahan.
Pada pembelajaran tanpa scientific mahasiswa terbagi menjadi beberapa golongan. Ada yang tergolong aktif karena mereka memiliki motifasi yang baik untuk kuliah. Sehingga membuat mahasiswa tersebut bergairah untuk mengikuti kegiatan pembelajaran, sering bertanya apa yang tidak dipahami. Ada yang tergolong biasa-biasa saja karena dimungkinkan malu untuk mengungkapkan ide-idenya dalam perkuliahan, sehingga hanya mendengarkan saja apa yang dijelaskan dosen. Ada juga yang tergolong pasif karena kemampuan dasar matematikanya lemah, sehingga mulai mengganggu temannya dalam mengikuti perkuliahan, ngobrol dengan teman sebangku, ada yang bermain $\mathrm{hp}$ dan ketika ditanya hanya senyum-senyum malu.

Permasalahan yang peneliti amati di lapangan (kelas) adalah kebanyakan mahasiswa masih sering mengalami salah hitung, salah memfaktorkan, dan salah mengoperasikan operasi hitung aljabar. Akibatnya penskoran hasil pembelajaran tidaklah maksimal. Konsep trigonometrinya sudah benar, tetapi pengoperasian bentuk aljabarnya yang sering mengalami kesalahan. Begitu juga permasalahan yang peneliti amati di kelas yang diajarkan tanpa scientific. Kebanyakan mahasiswa masih sering mengalami kekeliruan dalam pengoperasian bentuk aljabar. 


\section{KESIMPULAN DAN SARAN}

Berdasarkan hasil penelitian dan pembahasan, disimpulkan beberapa informasi sebagai berikut.

1. Rata-rata hasil belajar mahasiswa yang diberikan pendekatan scientific yaitu sebesar 24,06 dari skor maksimal 40. Artinya persentase hasil pembelajaran scientific sebesar $60,15 \%$ (tergolong cukup).

2. Rata-rata hasil belajar mahasiswa yang diberikan pembelajaran tanpa pendekatan scientific yaitu sebesar 20,72 dari skor maksimal 40. Artinya persentase hasil pembelajaran tanpa scientific sebesar 51,8\% (tergolong rendah).

3. Hasil belajar mahasiswa yang diajarkan menggunakan pendekatan scientific lebih baik daripada hasil belajar mahasiswa yang diajarkan tidak menggunakan pendekatan scientific.

Selanjutnya dari hasil penelitian yang diperoleh disarankan hal-hal sebagai berikut.
1. Dosen
mata
kuliah

Trigonometri hendaknya bisa membelajaran mata kuliah Trigonometri dengan pendekatan dan metode pembelajaran yang tepat, salah satunya scientific karena dinilai cocok antara karakteristik mata kuliah dengan karakteristik pendekatan tersebut.

2. Secara umum, memang hasil belajar mahasiswa yang diajarkan menggunakan pendekatan scientific lebih baik daripada hasil belajar mahasiswa yang diajarkan tidak menggunakan pendekatan scientific, Akan tetapi perlu diketahui bahwa kemampuan dasar pengoperasian aljabar mahasiswa baru angkatan 2014/2015 dapat dibilang lemah. Sehingga diperlukan perlakuan khusus dalam hal pembinaan atau pembelajaran tambahan mengenai pengoperasian aljabar. Walaupun konsep trigonometri dapat dikuasai mahasiswa, tetapi jika pengoperasian aljbarnya lemah, maka akan berakibat rendahnya hasil belajar trigonometri mahasiswa tersebut.

\section{DAFTAR PUSTAKA}

Arikunto, S. 2010. Dasar-dasar Evaluasi Pendidikan. Jakarta: Bumi Aksara.

Atsnan, M.F dan Gazali, R.Y. 2013. Penerapan Pendekatan Scientific Dalam Pembelajaran Matematika SMP Kelas VII Materi Bilangan (Pecahan). Prossiding. Makalah dipresentasikan pada tanggal 
ISSN 2442-5419 Vol. 4, No. 2 (2015) 30-41

9 november 2013 di UNY dengan tema Penguatan Peran Matematika dan Pendidikan Matematika Untuk Indonesia Yang Lebih Baik.

Baharudin dan Wahyuni, E.N. 2010. Teori Belajar dan Pembelajaran. Yogyakarta: Ar_Ruzz Media.

Fuzinoviyanti. 2013. Pendekatan Pembelajaran Scientific dan Kontekstual.

http://fuzinoviyanti.wordpres s.com/2013/10/27/pendekata n-pembelajaran-scientificdan-kontekstual/.

Hanafiah, N dan Suhana, C. 2009. Konsep Strategi Pembelajaran. Bandung: PT Refika Aditama.

Nawawi, H. 2005. Metode Penelitian Bidang Sosial. Yogyakarta: Gajah Mada University Press.

Sugiyono. 2007. Metode Penelitian Pendidikan. Bandung: CV. Alfabeta.

Undang-Undang Republik Indonesia Nomor 20 Tahun 2003 Tentang Sistem Pendidikan Nasional. Jakarta. 